\title{
Creating Shared Value in an industrial conurbation: \\ Evidence from the North Staffordshire Ceramics Cluster $^{1}$
}

By lan Jackson and Lorraine Limbrick

Staffordshire University Business School, UK

\section{Single sentence}

The evidence gathered from the North Staffordshire Ceramics cluster suggests that the real benefit of Porter and Kramer's work in Creating Shared Value may be to assess past events in capitalism rather than to predict the future.

\section{Key points}

The claims by Porter and Kramer that the concept of Creating Shared Value is an effective way of reinventing modern capitalism by releasing an upsurge in innovation is misleading because it maintains self-interest principally of large corporations at the centre of the economic system.

The long-term development of the North Staffordshire Ceramics cluster suggests that firms such as Wedgwood were developing a primitive form of CSV over 250 years ago at the start of capitalism as opposed to a recent way of reinventing modern capitalism.

The evidence of competitive forces remains strong and the resilience of firms in the cluster is much more in line with Schumpeterian "perennial gale of creative destruction" than a "wave of innovation and growth" offered by Porter and Kramer.

\section{Introduction}

The remarkable claim by Porter and Kramer (2011) that the concept of Creating Shared Value (CSV) is an effective way of reinventing modern capitalism by releasing an upsurge in innovation is both appealing and alarming at the same time. The assertion is appealing because it offers an optimistic vision for dealing with the manifest troubles of the postindustrial phase of capitalism; but it is also alarming because it maintains self-interest principally of large corporations at the centre of the economic system, Brittan (1996). In other words, although CSV provides potentially insightful observations, it is not the radical

${ }^{1}$ B12, L25, L61, R12 
departure from the pre-existing forms of capitalism, which is a fundamental aim of the approach.

As a result, while CSV has gained traction as a prospectus for accountable and transparent behaviour by business organisations and national regulators alike, it remains embedded in the prevailing approach and furthermore overlooks the paradoxical role of innovation in wider society. Hence, the contradictory feature of capitalism is captured not by CSV with a "wave of innovation and growth" (Porter and Kramer, 2011, p. 63); rather it is depicted perfectly by a "perennial gale of creative destruction" (Schumpeter, 1943, p. 83). This point is supported by the work of Galbraith (1952, p. 100) and furthermore by reference to the profound influence of technology companies in the dynamically changing landscape of the digital age such as Apple, Amazon, Facebook, Google, Microsoft and many others. More recently this view has been progressed by Haskel and Westlake (2018, p. 13) as the rise of the intangible economy referred to "capitalism without capital".

This paper is divided into five remaining parts. The first section provides an overview of the research method and approach. The second section is a critique of CSV with specific reference to the development of local clusters in conurbations such as the North Staffordshire Ceramics agglomeration. The third section assesses evidence from business history that ceramics firms such as Josiah Wedgwood and Sons ${ }^{2}$ were possibly developing a primitive form of CSV over 250 years ago at the start of capitalism. The fourth section presents contemporary evidence from the North Staffordshire Ceramics industry regarding the role of cooperation and competition. The final section presents the conclusions generated by the empirical research.

\section{Research Method and Approach}

Shared value can be created in three main ways; namely, (1) producing commercial output to benefit the public good, (2) orientating productivity to benefit wider society and (3) facilitating the development of local clusters (Porter and Kramer, 2011, p. 67). All three ways add societal value at the firm-level and Porter and Kramer claim that CSV is fundamental to wider community profitability as opposed to short-term profit maximising by

\footnotetext{
${ }^{2}$ The Wedgwood company had several broadly similar names at the beginning of its existence including Wedgwood and Bentley, which celebrated the collaboration between Josiah Wedgwood and his business partner Thomas Bentley.
} 
companies. This hypothesis is generated because firms do not operate is isolation and logic dictates they are more likely to contribute greater amounts of productivity when embedded within connected markets and integrated clusters because of synergy. As a direct consequence, there is often a need for government initiatives on industrial policy rather than allowing individual firms and whole industries to operate independently and unregulated (see Bailey, Cowling and Tomlinson, 2015 for a comprehensive account of Industrial Policy in a British context).

Despite its reputation as a wide-ranging approach that offers compelling analysis to the term “conscious capitalism” (O'Toole and Vogel, 2011, p. 75), CSV is criticised as an unoriginal idea and for promoting an unsophisticated conceptualisation of the firm (Crane et al., 2014, p. 132). Therefore, the motivation for this research is twofold. One, to explore the potential antecedents of CSV at the beginning of capitalism during the mid-eighteenth century, which allows an assessment of whether the idea is new or not. Two, to identify the modern approach of the firm and to assess whether companies are cooperative within a specific cluster or remain competitive and broadly independent from one another.

As a result, the research method and approach of this research is to assess the theoretical domain of CSV and its related premises by using both historical and contemporary data. This method is based on a business case history approach rather a longitudinal data-set for two reasons. Firstly, assessing the available data at the beginning of the cluster formation and during the maturity phase will allow the findings to be much more nuanced and permit a deeper understanding of the organisational features being examined. Secondly, the business history approach combined with contemporary evidence extends the span of the study period over a much a long period of time. The next section outlines the centrality of clusters on the approach of CSV.

\section{Shared Value and the Centrality of Clusters}

The notion of shared value has an intuitive appeal. If indeed "the capitalist system is under siege" Porter and Kramer (2011, p. 64) and furthermore if Corporate Social Responsibility (CSR) is not helping sufficiently enough to improve the persistent crisis in capitalism, then an approach that improves competitiveness while at the same time enhancing economic and social conditions without any obvious trade-offs is undoubtedly attractive. This is because the concept of opportunity cost is central to economics and a lack of trade-offs challenges the 
entire doctrine. This means that the immediate criticism of the approach is that Shared Value may be an unobtainable illusion or the result of repeating "a management buzzword" ad infinitum (Dembek et al., 2016). Consequently, Shared Value may not be feasible as it could be the product of wishful thinking motivated primarily because capitalism continues to struggle after another damaging crisis post-2007-08.

In principle, Porter and Kramer (2006) specify shared value in terms of reconfiguring products and markets; redefining productivity within a value chain and reimagining the location of industrial clusters such that benefit to wider society is accomplished. As with Porter's previous work, it is apparent that clusters are central to the strategic analysis (Porter, 1990). This outcome is based loosely on the Game Theoretic notion of a "win-win" situation; see de los Reyes, 2017 for further details. That is, the contract or transaction is completed because there is a mutual benefit for two or more parties involved in the process of exchange (whether economic, social or some combination thereof). Nevertheless, it is not necessarily the case that firms benefiting from co-location in a cluster enhance the community socially as well as economically. Consequently, it may be that firms must be educated or indeed encouraged to share value as it is not always an obvious thing to do. In addition, even in a "win-win" the pay-off may be distributed asymmetrically that leads to the costs of widening inequality rather than the benefits of group sharing.

In practice, the costs and benefits of CSV at both the societal level and the organizational level remain rather difficult to measure. In terms of co-location as a focus of this paper, from the 95 empirical examples cited by Dembek et al. (2016) only three involved clusters and all three of these studies were cited by Porter and Kramer in 2011 without elaborating fully. Note all the others were either value chain or product related and unexpectedly over half were not identified as any of the three areas. In summary, the case of Nestle creating coffee clusters to increase yields and reduce the environmental impact for society while creating reliable supplies of coffee for the company, does not specify any costs. The case of Technoserve partnering global and local agricultural clusters in 30 countries has no costs and benefits at any level; although the case of Yara creating growth corridors in Mozambique and Tanzania does specify that the benefits to society of employment and the benefit to the organization of business growth did cost the organization $\$ 60$ million. Overall, these three case studies presented by Porter and Kramer do not constitute a compelling evidence base for championing CSV with respect to the central cluster element.

Notwithstanding, cluster analysis is nothing new. A whole century even before Porter's Five Forces Model, Marshall was extolling the virtues of the cluster (Marshall, 1890, p. 222). One 
example Marshall used to illustrate the advantages of highly-specialized production in a single location was the Staffordshire pottery industry. The manufacture of ceramics is soclosely associated with the six towns comprising Stoke-on-Trent ${ }^{3}$ that the entire area is referred to as the Potteries. Throughout the seventeenth and eighteenth centuries, the master potters of North Staffordshire had become known for manufacturing durable products. Nevertheless, it was the abundance of coal to fire the kilns and the exceptional skills of the local workforce along with the business leadership of Josiah Wedgwood (1730-1795) that combined to established a world-famous industrial cluster (Belussi and Caldari, 2009). The next section explores the primitive origins of CSV at the early stages of capitalism (as opposed to the latter stages of maturity more recently) and back to the time when Wedgwood established intra-firm division of labour (i.e. within firms) at his factory while simultaneously he pioneered brand management, cost accounting and other technical innovations.

\section{Primitive Forms of Shared Value and the Legacy of Josiah Wedgwood}

The roots of Shared Value according to Porter and Kramer is the symbiotic relationship between firms and society. Hence:

"At the very basic level, the competitiveness of a company and the health of the communities around it are closely intertwined. A business needs a successful community, not only to create demand for its products but also to provide critical public assets and a supportive environment."

Porter and Kramer, 2011, p 66.

This is an inexplicable statement given that capitalist firms are known to be "footloose" in switching locations to the area with the lowest production cost; and often prefer negotiating at "arms-length" with labour unions, direct suppliers, community groups and other noncorporate stakeholders. In any case, the true origins of CSV may well be further back in time at the embryonic stage of capitalism and even before Adam Smith wrote the "Wealth of Nations" in 1776. To explore this proposition further, the business history of Josiah Wedgwood will be assessed from the emerging CSR viewpoint. This is because an investigation of this nature may prove that there is nothing new or even novel about CSV.

\footnotetext{
${ }^{3}$ The six towns are Burslem, Fenton, Hanley, Longton, Stoke-upon-Trent and Tunstall; all of which amalgamated to form the federated City of Stoke-on-Trent in 1910.
} 
When Josiah Wedgwood initially established his own company in 1759, North Staffordshire remained a relatively isolated agricultural area of farmsteads some with a single kiln attached to outhouses for the small-batch production of earthenware often used for transferring butter and cheese further afield ${ }^{4}$. However, the patterns of work were irregular and usually concentrated on a master potter together with a few apprentices and casual workers. The local transportation links were especially poor around the market-town of Burslem where the original Wedgwood factory was located and so moving raw material and finished goods in and out of the area was logistically problematic, costly and wasteful in terms of damage to finished goods.

Undaunted, Wedgwood first helped to improve the road system with the construction of nine turnpikes completed by 1766 and then by personifying the driving force behind the construction of the "Grand Trunk" connecting the Trent and Mersey rivers, which opened in 1777. This major transportation advance effectively transferred the coal and clay to the factories and moved the finished pottery goods to national and international markets. This significant technological development undoubtedly helped Wedgwood in his business organisation but not exclusively as all the other pottery companies also benefitted from the vastly improved transportation links to and from the Potteries, such as William Adams (established 1769), John Ansley (established 1775) and Josiah Spode (established 1770) amongst others. This is potential evidence that Wedgwood was creating an early form of Shared Value not least as his actions profited his business rivals with whom he helped to establish a local pottery manufacturers association to the mutual benefit of its members.

In addition, Wedgwood prospered through several inspirational product innovations such as producing green glaze in 1759, black basalt stoneware in 1768 and eventually world famous Creamware and Jasperware both in the 1770s. However, all these product improvements could be easily copied by other pottery companies in the locality. The process innovations that Wedgwood introduced, once he moved to a purpose-built factory at Etruria in 1769, included initiating the large-scale intra-firm division of labour (rather than small-scale production being based around a master potter), rudimentary industrial training, waste reduction schemes, quality assurance measures and elementary cost accounting all which created an accepted industrial standard. Also, Wedgwood developed the pyrometer for

\footnotetext{
${ }^{4}$ This movement of goods was achieved through an incomplete system of turnpikes supplemented by in-land water navigation routes along the river Weaver and Trent that transported goods to the main ports such as Liverpool and Hull.
} 
accurately measuring kiln temperatures (rather than educated guesswork via trail and error) which got him elected to the Royal Society in 1782. However, these improvements did not necessarily make Wedgwood's own products any cheaper as the competitors quickly followed suit. Again, this is possible evidence that Wedgwood was creating what has become known as shared value for all the Staffordshire Potters rather than trying to gain a decisive competitive advantage. Of course, this could be a symptom of the age and Wedgwood was a member of the celebrated Lunar Society ${ }^{5}$ that promoted science and knowledge. However, Wedgwood had remarkable business acumen and it is possible that he knew that he would benefit from being co-located with other potters where there could be inter-firm division of labour (i.e. between firms), as the supplier-base developed such as Jesse Shirley bone and flint mill. This analytical approach is summarized in Table 1, which is based on a literature survey conducted by Dembek at al., (2016) and updated here to incorporate the costs and benefits of Josiah Wedgwood's business on society and the organisation itself.

\section{[Insert Table 1 here]}

Remarkably, it was in marketing innovations that Wedgwood managed to keep significantly ahead of his competitors. The promotion of the Wedgwood brand name through a distinctive back-stamp and company icon; the opening of London showrooms and the staging of spectacular exhibitions; the publishing of unique product catalogues and price discrimination; the production of showcase items such as the Portland Vase plus newspaper advertising and product placement throughout the final quarter of the eighteenth century projected the Wedgwood image worldwide. As a result, it is commonly acknowledged that Wedgwood created the first-ever marketing plan and pioneered the concept brand management. As a result, it was through these intangible marketing innovations rather than the tangible process, product and organisational innovation that made Wedgwood pottery world-famous, hugely popular and commercially successful.

Overall, it could be argued that Wedgwood was satisfied for the other Staffordshire pottery companies to benefit from his commercial acumen and business leadership if the local cluster

\footnotetext{
${ }^{5}$ Some of the other famous contemporary members of the Lunar Society included Matthew Boulton, Erasmus Darwin, Joseph Priestley and James Watt.
} 
prospered. In turn, the Wedgwood company would gain from a developed supply chain, a locally available workforce as well as other early industry-related institutions and associations. Therefore, the argument in favour for CSV may be strongest at the beginning of capitalism rather than the end. Or at least, CSV may be most beneficial for communities starting-out at the embryonic stage or playing catch-up when beginning from a low base or later. If this is the case, then the real benefit of Porter and Kramer's work is to assess past events as opposed to predict the future. The next section looks at Shared Value in terms of the modern ceramics industry in North Staffordshire from the point of view of cooperation and competition.

\section{Contemporary Evidence of Shared Value from North Staffordshire Ceramics Cluster}

The North Staffordshire Ceramics cluster has existed for over 250 years and has produced ceramic goods of all kinds including tableware, tiles, ornaments, bricks and refractory ceramics used in a wide range of applications such as the automotive, electronics and medical industries. The ceramics industry in the area employs approximately 8,700 people and contributes about $£ 285$ million of gross value added to the Stoke-on-Trent local economy in 2014 (British Ceramics Federation, 2017, p.5). In recent times, there have been many highprofile closures such as Royal Doulton in 2005 and Spode in 2008, but latterly there has been a renaissance as remnants of the cluster have prospered in niche markets such as art pottery produced by Moorcroft and specialised products for hotels and the catering sector by larger firms including as Churchill, Dudson and Steelite International (see Tomlinson and Branston, 2014 and Ewins, 2017 for a comprehensive account of the recent growth trends including business start-ups and exports).

This research assesses evidence from the 16 tableware and giftware companies ${ }^{6}$ remaining in North Staffordshire in 2016-17 and aims to consider competitive advantage in the North Staffordshire Ceramics Industry cluster by looking at innovative output. It analyses at the interaction between competition and co-operation within the cluster itself and assesses the contribution that each has made to the industry. By this approach, the extent of any Shared Value in the Ceramics Cluster can be assessed fully as the cluster is in its maturity phase. Therefore, the main research methodology focuses on a single case study, where the North

\footnotetext{
${ }^{6}$ There were 107 tableware and giftware companies in 1960 defined as those firms producing and decorating ceramic products. This date is before considerable consolidation in the industry in which the two firms became dominant; namely, Wedgwood and Royal Doulton through a series of mergers and acquisitions.
} 
Staffordshire cluster is defined as a single entity for the purposes of this research because it represents virtually the whole of the UK ceramics production industrial sector, i.e. approximately $80 \%$. Furthermore, a single case study approach is particularly suited to investigating a concentrated industry cluster, see Porter, 1990; Dayasindhu, 2002; Zhang et al., 2004. In this case study, the research involved a structured interview with six of the remaining firms, who were representative of the various product ranges and company sizes, as well as accounting for $60 \%$ of the employment in this sector of the cluster.

The phenomenon of clustering is based on the exchange and flow of information and knowledge between buyers, suppliers and related industries that ultimately leads to innovative output (Porter, 1990). These interchanges are termed 'positive' forms of cooperation and are considered in the economic literature as 'cluster externalities' (HervasOliver and Albors-Garrigos, 2009). There is much evidence to be found, across a range of different literatures, that links co-operation and successful clusters. For example, Dei Ottati (1994) in his work on industrial districts, argues that co-ordination through co-operation and the inseparable linking of this with the market is what distinguishes the industrial district as a model of organisation. According to Camagni (2002), the industry cluster or region is described as "a system of localised technological externalities, social relations and local governance" (p. 2396). This is highlighted by Marshall in 1890, when he first used the term 'industrial atmosphere'. Since then a variety of terms have been used to refer to a cluster's external resources including, 'social complexity' (Piore \& Sabel, 1984), and 'non-traded interdependencies'.

From the research findings, competition has reduced in the North Staffordshire cluster due to severe consolidation since 1960. That is, there are currently far fewer firms in the cluster than in 1960. Consequently, there is significantly less local competition. Moreover, the findings indicate that there have only been three new entrants in the North Staffordshire cluster since 1960 that have grown to any significant size. The first is Emma Bridgewater, a genuine new entrant, i.e. brand new start up firm and now the sixth largest firm in the cluster. The second is Steelite International, the cluster's current largest firm that was a spin-off from Doulton and so not a 'true' new entrant. The third is Portmeirion, another actual new entrant and currently the second largest firm in the North Staffordshire cluster. Nevertheless, the interview findings clearly indicate, that despite operating in different market niches, and so not directly competing, vigorous domestic rivalry is taking place between cluster firms, evidenced by high levels of product, process, organisational and marketing innovations. 
Hence, these findings also indicate that cluster firms view each other as close competitors and they fiercely protect their innovations and new product ideas from each other. Moreover, intense global competition in all key markets has been shown to be another driver of competition between the cluster firms. Overall, the North Staffordshire cluster remains a moderately successful cluster, demonstrating vigorous competition between cluster firms, evidenced by strong innovative output, despite a significant decrease in the overall number of firms and very few new entrants. Hence, it would seem there is not sufficient scope for CSV if the firms view each other as close rivals.

Also, the findings indicate that the cluster's past dominant firms appear to have engaged in competitive strategies that resulted in a reduction in co-operation and innovation in the cluster. As widely accepted, Wedgwood and Royal Doulton are thought to be responsible for much of the consolidation that significantly reduced the number of firms in the cluster which, in-turn, also reduced competition in the cluster. A reduction in competition, simply because there are fewer firms, reduces the overall innovative capacity of the North Staffordshire cluster. Moreover, the findings indicate that a major motive for the effective duopoly of Wedgwood and Royal Doulton's acquisition strategies was deliberate elimination of competition. The findings also indicate that Wedgwood and Royal Doulton did not share their knowledge with the rest of the local cluster, and this would have affected opportunities for knowledge exchange (co-operation) within the cluster. According to Sacchetti and Tomlinson (2009), lead firms might prefer their knowledge to remain hidden since it strengthens its hold over its strategic options and capabilities, particularly in relation to technological change (p. 1843), and this appears to be the case with Wedgwood and Royal Doulton. Although the cluster duopoly position has been reduced since Royal Doulton ceased trading in 2005 and Wedgwood operates at reduced scale since 2009, nevertheless the legacy of this is that the firms and supporting institutions in the cluster do not share value in the way imagined by Porter and Kramer. This is not surprising as firms should maintain independence and avoid any accusations of collusion.

According to Giuliani and Bell (2005), the presence of firms with a stronger knowledge base in clusters is associated with denser and better connected intra-cluster knowledge systems. These 'leading firms' (Lazerson and Lorenzioni, 1999) or 'technological gatekeepers' (Giuliani, 2013; Grandinetti, 2016) are mainly responsible for acquiring external knowledge and subsequently transferring it as specific 'know-how' adapted to each cluster, or as operational knowledge to be exploited in local clusters. When knowledge is transferred in this 
way it contributes to the 'industrial atmosphere' (Marshall, 1890: 287) of the cluster and helps to avoid lock-in. However, as Marshall also acknowledges, lead firms in clusters do not always share their knowledge with other cluster members and this can be to the detriment of the cluster. In the UK ceramics cluster, possibly due to these conditions, the need for coordination has historically been low. Moreover, according to Sacchetti and Tomlinson (2009), since the 1970s the ceramics cluster has consolidated and evolved towards a more hierarchical mode of economic governance, with lead firms having a major negative impact on the 'shape' and 'direction' of the cluster. As Sacchetti and Tomlinson state: “...the larger ceramics firms have neglected the cluster's longer-term development, in particular in relation to new investment capacity and the skills base" (p. 1854). However, this could be an opportunity for CSV in the future despite continuous change along the lines envisaged by Schumpeter.

Furthermore, Dei Ottati (1994) recognise the need for a balance between co-operation and competition in the industrial district; that is 'the stability of the industrial district over time calls for internal competition and co-operation to be well behaved and to stay together in a reciprocally balanced relationship" (p. 474). Hence, the need for the involvement of formal and informal institutions to support and regulate the industry. Moreover, the benefits of collaboration can overcome the negative externalities of corrosive competition and diseconomies of scale (Raco, 1999). Particularly for small firms, co-operation in the establishment of marketing or training facilities, or of R\&D laboratories, may allow them to gain access to economies of scale, scope and agglomeration, whilst enhancing competition in the product market (Oughton and Whittam, 1997; Newlands, 2003). Competition between firms may provide market disciplines which ensure the continued competitive advantage of a cluster and, in turn, attract new firms to it. Thus, co-operation and competition become a mutually reinforcing positive relationship (Newlands, 2003), that raises the average level of competitiveness of firms and systems (Belussi and Sedita, 2009). When the cluster reaches a balance between co-operation and competition the interplay between the two can be dynamic and can act to prime a kind of virtuous circle (Dei Ottati, 1994). In other words, CSV cannot simply be on the basis on cooperation (see Szmigin and Rutherford, 2013).

\section{Conclusions}


This paper has attempted to assess the notion of CSV by using the evidence from a business history approach at the start of a cluster formation and then later in the maturity phase. The span of over 250 years has been used to show the possibility of how shared value can be created in the long-term. The main conclusions from this research suggest that the competitive forces remain strong and that the Schumpeterian "perennial gale of creative destruction" (Schumpeter, 1942, p. 83) is more relevant to present-day business than a "wave of innovation and growth" (Porter and Kramer, 2011, p. 63). In part, this is the result of many decades of firms competing fiercely against one another and due to strong brand identity often going back to the eighteenth and nineteenth century. In other words, the evidence from the North Staffordshire ceramic industry is that firms continue to compete both inside and outside the cluster as a response to turbulent economic conditions; rather than working together to improve productivity at a company level or even to overcome systemic failures at the cluster level (Porter and Kramer, 2011, p. 72).

It has been discussed that co-operation in clusters is based on interchanges that facilitate the exchange and flow of information and knowledge in the cluster (i.e. between buyers, suppliers and related industries) that ultimately leads to innovative output. These interchanges (i.e. linkages) accrue unique agglomeration benefits to cluster members by lowering production costs. However, there does not seem to be much evidence of close cooperation in the North Staffordshire cluster and so there is probably limited scope for creating any shared value in the short or medium term.

Finally, it has been debated that competition is a key driver of innovation within clusters. The greater the number of firms there are in the cluster, the more vigorous competition will tend to be between cluster firms and hence, the greater the potential to innovate. Moreover, because of dynamic agglomeration benefits, innovations will happen earlier and will be brought to market more quickly. Thus, there does not seem to be any desire for creating a shared value at the mature stage of the cluster life cycle. Nevertheless, there was significant evidence for this type of activity on the threshold of the capitalist system by the first Josiah Wedgwood in the final quarter of the eighteenth century. A possible explanation for this result is that CSV is better at describing past events rather than predicting the future. If this is the case then the recent evidence gathered in the North Staffordshire Ceramics Cluster casts serious doubt on the CSV concept becoming the "key to unlocking the next wave of business innovation and growth" (Porter and Kramer 2001, p. 77). 


\section{References}

Bailey, D., Cowling, K. and Tomlinson, P. (2015). New Perspectives on Industrial Policy for a Modern Britain. Oxford: Oxford University Press.

Belussi, F. and Caldari, K. (2009). At the Origin of the Industrial District: Alfred Marshall and the Cambridge School. Cambridge Journal of Economics 33 (2), pp. 335-355.

Belussi, F. and Sedita, S. (2009), Life-cycle vs. Multiple Path Dependency in Industrial Districts, European Planning Studies, 17 (4), pp. 505-528.

British Ceramic Federation (2017). A Deal for Ceramics. Stoke-on-Trent: British Ceramics Federation and Staffordshire Partners.

Brittan, S. (1996). Capitalism with a human face. London: Fontana Press.

Camagni, R. (2002). On the Concept of Territorial Competitiveness: Sound or Misleading? Urban Studies, 39 (13), pp. 2395-2411.

Crane, A., Palazzo, G., Spence, L. and Matten, D. (2014). Contesting the value of "Creating Shared Value". California Management Review 56 (2), pp. 130-149.

Dayasindhu, N. (2002). Embeddedness, Knowledge Transfer, Industry Clusters and Global Competitiveness: A Case Study of the Indian Software Industry, Technovation, Volume 22, pp. 551-560.

Dei Ottati, G. (1994). Co-operation and Competition in The Industrial District as an Organisational Model, European Planning Studies, 2 (4), pp. 463-483.

De los Reyes, G., Schilz, M. and Smith, N. (2017). Beyond "win-win": creating shared value required Ethical Frameworks, California Management Review, 59 (2), pp. 463-483.

Dembek, K., Singh, P. and Bhakoo, V. (2016). Literature Review of Shared Value: A Theoretical Concept or a Management Buzzword? Journal of Business Ethics 137 (1), pp. 231-267.

Ewins, N. (2017). Ceramics and Globalisation: Staffordshire Ceramics, Made in China. London: Bloomsbury Publishing.

Galbraith, J. (1952). American Capitalism: The Concept of Countervailing Power. Harmondsworth: Pelican Books. 
Giuliani, E. (2013). Network Dynamics in Regional Clusters: Evidence from Chile, Research Policy, Volume 42, pp.1406-1419.

Giuliani, E. and Bell, M. (2005). The Micro-determinants of Meso-level Learning and Innovation: Evidence from a Chilean Wine Cluster, Research Policy, Volume 34, pp. 47-68.

Grandinetti, R. (2016). Absorptive Capacity and Knowledge Management in Small and Medium Enterprises, Knowledge Management Research \& Practice, Volume 14, pp. 159168.

Haskel, J. and Westlake, S. (2018). Capitalism without Capital. Princeton: Princeton University Press.

Hervas-Oliver, J. L. and Garrigos, J. A. (2009). The Role of the Firm's Internal and Relational Capabilities in Clusters: when Distance and Embeddedness are not Enough to Explain Innovation, Journal of Economic Geography, Volume 9, pp. 263-283.

Lazerson, M. and G. Lorenzoni, (1999). Resisting Organizational Inertia: The Evolution of Industrial Districts, Journal of Management and Governance, Volume 3, pp. 361-377.

Marshall, A. (1890). Principles of Economics: An Introductory Volume. London: MacMillan.

Newlands, D. (2003). Competition and Cooperation in Industrial Clusters: The Implications for Public Policy, European Planning Studies, 11 (5), pp. 521-532.

Oughton, C. and Whittam, G. (1997). Competition and Cooperation in the Small Firm Sector, Scottish Journal of Political Economy, 44 (1), pp. 1-30.

O’Toole, J. and Vogel, R. (2011). Two and a Half Cheers for Conscious Capitalism. California Management Review 53 (3), pp. 60-76.

Piore, M. and Sabel, C. (1984). The Second Industrial Divide. New York: Basic Books.

Porter, M. (1990). The Competitive Advantage of Nations. New York: Free Press.

Porter, M. and Kramer, M. (2006). Strategy and Society: The Link between Competitive Advantage and Corporate and Social Responsibility. Harvard Business Review 84 (12) December, pp. 78-92.

Porter, M. and Kramer, M. (2011). Creating Shared Value: how to reinvent capitalism and unleash a wave of innovation and growth. Harvard Business Review 89 (1) January-February, pp. 62-77. 
Raco, M. (1999). Competition, Collaboration and the New Industrial Districts: Examining the Institutional Turn in Local Economic Development, Urban Studies, 36 (5-6), pp. 951- 968.

Sacchetti, S. and Tomlinson, P. (2009). Economic Governance and the Evolution of Industrial Districts Under Globalisation: The Case of Two Mature European Industrial Districts, European Planning Studies, 17 (12), pp. 1837-1859.

Schumpeter, J. (1943). Capitalism, Socialism and Democracy. London: George Allen and Unwin.

Smith, A. (1776). The Wealth of Nations. Cannon Edition.

Szmigin, I. and Rutherford, R. (2013). Shared Value and the Impartial Spectator Test. Journal of Business Ethics 114 (1), pp. 171-182.

Tomlinson, P. and Branston, R. (2014). Turning the tide: industrial Renaissance in the North Staffordshire Ceramics District. Cambridge Journal of Regions and Society 7 (3), pp. 489507.

Zhang, Z., To, C. and Cao, N. (2004). How do Industry Clusters Success: A Case Study in China's Textiles and Apparel Industries, Journal of Textile and Apparel Management, 4 (2), pp. 1-10.

Ian Jackson is an Enterprise Reader at Staffordshire University Business School, UK. His main areas of teaching include all aspects of microeconomics and his primary research focus covers innovation, productivity and industrial policy.

Lorraine Limbrick is a Senior Lecturer at Staffordshire University Business School, UK. Her main areas of teaching are International Strategic Management. Her primary research focus is on the competitive advantage of places, specifically on industry clusters.

Corresponding author:

Ian Jackson

Staffordshire University Business School

Leek Road

Stoke-on-Trent

ST4 2DF

United Kingdom

E-mail: I.jackson@staffs.ac.uk 